\title{
ANALISIS STRATEGI MOMENTUM DIBURSA EFEK INDONESIA (Pada Perusahaan Manufaktur)
}

\author{
Nova Begawati, S.E., M.M. \\ NIDN. 1027118802 \\ Lecturer at Management Study Program of Economic Faculty, Ekasakti University \\ Jalan Veteran Dalam No. 26 B Padang (25113) Indonesia
}

\begin{abstract}
Abstrak
Penelitian ini bertujuan untuk membuktikan adanya penerapan momentum strategi di Bursa Efek Indonesia. Pada penelitian ini digunakan beberapa perusahaan manufaktur yang listed di Bursa Efek Indonesia. Data yang digunakan adalah data sekunder dalam bentuk perkembangan harga saham perusahaan secara individu, dan indeks harga saham gabungan (IHSG) yang diperoleh dari web-side www.yahoo.com/finance dan www.idx.co.id. Data yang digunakan adalah data bulanan dari tahun $2002-$ 2012. Untuk melakukan tahapan pengolahan data maka digunakan pengujian uji beda dengan menggunakan uji statistik. Berdasarkan hasil pengujian diperoleh hasil yang menunjukan adanya perbedaan cumulative average abnormal return setelah dilakukan pengurangan antara perusahaan winner dengan loser. Kecenderungan yang terbentuk menunjukan bahwa nilai rata rata cumulative average abnormal return perusahaan winner berada diatas 0 dan nilai t-hitung bertanda positif yang menunjukan bahwa perusahan winner tidak mengalami perubahan posisi begitu pun dengan perusahaan loser kecenderungan pergerakan harga saham dan abnormal return yang diperoleh investor terus mengalami peningkatan. Kondisi ini. menunjukan implementasi momentum strategi berjalan dengan efektif.
\end{abstract}

Kata Kunci Investment Momentum Strategy, Abnormal Return, Cumulative Average Abnormal Return, Winner, Loser

\section{Abstrak}

This study attempts to prove the existence of the application of momentum strategy in the indonesian stock exchange.To research is used some manufacturing companies who listed at the indonesian stock exchange.The data used was secondary data in the form of the development of stock prices company. individually, and composite stock price index (IHSG) obtained from web-side www yahoo com / finance and www. idx.co.id.The data used was monthly data from year 2002 - 2012.To do stage data processing so used testing test different by using statistical tests. Based on the results of testing the results that is indicative of differences in cumulative average abnormal return after conducted reduction between the company winners with loser. The formed showed that value on average cumulative average abnormal return company winners was sitting on 0 and value t-hitung marked positive which showed that company winners has not changed position it is with a company loser a tendency stock price movements and abnormal return obtained investors continues to increase. The condition showed the implementation of momentum strategy effective.

Kata Kunci Investmen Momentum Strategy, Abnormal Return, Cumulative Average Abnormal Return, Winner, Loser

\section{PENDAHULUAN}

Investor bersifat irasional dan menginginkan menjual saham-saham yang berkinerja buruk dengan cepat untuk menghindari kerugian sebelum informasi yang sebenarnya tersebar secara merata (De Bond dan Theler, 1985). Salah satu acuan yang menjadi indikator yang mendorong investor melakukan pelepasan dan pembelian saham adalah momentum yang terbentuk. Investor cenderung akan menjual perusahaan loser. Indikasi loser terbentuk didalam image pelaku pasar momentum dimasa lalu menunjukan perusahaan tersebut memiliki kinerja keuangan dan saham dengan nilai pasar yang biasa saja dan tidak jarang mengalami undervalue, keadaan mendorong investor yang pada umum 
takut menghadapi risiko dan menderita kerugian lebih memilih perusahaan winner.

Keputusan seorang investor untuk membeli saham perusahaan winner adalah untuk menghindari risiko dan kerugian yang besar, sedangkan jika dilihat dari sisi perusahaan momentum yang menunjukan mereka berada dalam posisi winner tentu membuat manajemen perusahaan lebih bersemangat untuk terus mempertahankan posisi tersebut. Untuk menjaga momentum agar selalu berada dalam posisi winner tentu manajemen berusaha menjaga stabilitas kinerja keuangan yang mereka miliki. Pasar modal merupakan tempat yang fleksible dan selalu rentan dengan risiko, sungguh menjadi tantangan yang sangat besar bagi perusahaan untuk menjaga momentum sebagai perusahaan winner. Secara logika perusahaan tentu dapat terus maju dan berkembang, oleh sebab itu tidak menutup kemungkinan perusahaan yang dimasa lalu berada didalam posisi loser beralih berganti predikat menjadi winner.

\section{Perumusan Masalah}

Berdasarkan kepada latar belakang masalah, maka diajukan sebuah permasalahan yang akan dibuktikan didalam penelitian ini yaitu sebagai berikut: Apakah terjadi momentum investasi strategi pada perusahaan manufaktur winner dan loser di Bursa Efek Indonesia periode 2002-2012?

\section{Tujuan Penelitian}

Tujuan dari penelitian ini adalah untuk membuktikan secara empiris terjadinya momentum investasi strategi pada perusahaan manufaktur winner dan loser di Bursa Efek Indonesia.

\section{TINJAUAN LITERATUR}

Sebelum kita mengetahui apa yang dimaksud dengan strategi portofolio momentum terlebih dahulu harus diketahui bentuk bentuk strategi investasi yang dapat digunakan oleh investor seperti yang terlihat pada sub bab dibawah ini:

\section{Passive Strategy}

Strategi ini merupakan hasil dari kepercayaan investor dalam pasar efisien, sehingga mereka mempercayai bahwa harga saham merupakan sebuah estimasi terbaik dari nilai saham tersebut. Menurut Tandelilin (2001) secara garis besar passive strategy terdiri dari dua jenis strategi yaitu buy and hold strategy dan index fun.

Dalam melakukan passive strategy seorang investor cukup memilih saham saham tertentu dengan return dan risiko yang disesuaikan pertimbangan mereka. Untuk buy and hold strategy mereka hanya sekali membeli untuk kemudian memegangnya untuk waktu yang lama, selain itu strategi investasi passive juga dapat efektif dilasakanakan pada index fund. Index fund menunjukan investasi yang dilakukan berdasarkan indeks gabungan didalam sebuah negara. Proses tersebut dilakukan dengan beberapa asumsi yaitu pasar sangat efisien, investasi dilakukan dengan biaya yang efisien, investasi dilaksanakan secara aktif dan investasi yang dilakukan memiliki keuntungan terhadap pajak.

\section{Active Strategy}

Investor yang melakukan strategi active berbeda pendapat dengan investor yang melakukan passive strategy. Didalam passive strategy seorang investor sangat aktif untuk melakúkan pengumpulan informasi dan melakukan berbagai tindakan spekulatif untuk mendapatkan abnormal return. Semakin baik kemampuan seorang investor didalam mencari informasi yang cepat dan tepat dan melakukan spekulasi apakah menjual atau membeli saham baru tentu akan mempengaruhi keuntunagn investasi yang akan diperoleh.

Seorang investor yang mengembangkan Active Strategy cenderung untuk melakukan spekulasi jangka pendek dalam hal ini salah satu Active Strategy yang paling dikenal adalah momentum, didalam metode tersebut pasar atau investor harus jeli memilih saham yang dikategorikan winner dan menjual saham yang memiliki kategori loser. Spekulasi dengan membeli saham yang berada pada posisi winner dengan mengasumsikan bahwa momentum akan tetap mendorong terjadi peningkatan pada nilai pasar saham. 


\section{Momentum Investmen Strategy}

Strategi investasi menggambarkan bagaimana perilaku seorang investor mengatur investasinya. Didalam penentuan strategi investasi salah satu metode yang digunakan adalah pembentukan portofolio. Didalam pembentukan strategi portofolio ada dua jenis strategi yang digunakan yaitu portofolio aktif dan portofolio pasif. Strategi portofolio pasif meliputi tindakan manajer yang cenderung pasif dalam berinvestasi pada saham dan hanya mendasarkan pergerakan sahamnya pada pergerakan indeks pasar. Artinya investor tidak secara aktif mencari informasi atau melakukan jual beli saham yang bisa menghasilkan abnormal return.

Pada portofolio aktif pada dasarnya akan meliputi tindakan investor secara aktif dalam melakukan pemilihan dan jual beli saham, mencari informasi, mengikuti waktu dan pergerakan harga saham serta berbagai tindakan aktif lainnya untuk menghasilkan abnormal return. Dalam melaksanakan strategi ini seorang investor tentu harus berhati hati dalam mengambil tindakan yang berhubungan dengan investasi (Jones, 2002).

Portofolio momentum merupakan salah satu strategi portofolio aktif yang dapat digunakan investor dan manajer investasi untuk meningkatkan kinerja portofolio saham. Strategi ini dilakukan dengan cara membeli saham yang sebelumnya memiliki kineja yang baik dan menjual saham yang sebelumnya yang memiliki kinerja yang buruk (Sharpe et al 1995). Dalam strategi ini investor akan mencari momentum atau waktu yang tepat, pada saat harga saham tentu memberikan keuntungan bagi investor yaitu melalui tindakan menjual saham.

\section{Penelitian Terdahulu}

Zarowin (1990) menemukan bahwa kecenderungan saham loser mengungguli saham winner tidak tergantung pada reaksi berlebihan, tetapi adanya perbedaan ukuran perusahaan saham loser yang lebih kecil dari pada ukuran perusahaan saham wimner. Hal ini disebabkan karena terjadinya kapitalisasi pasar oleh perusahan skala besar. Hasil penelitian tersebut perusahaan winner selalu berusaha menjaga momentum berada dalam posisi winner. Asness (1997) dalam penilitiannya menyimpulkan bahwa hubungan nilai dan momentum untuk keuntungan masa mendatang tidak hanya kuat memegang variabel konstan lainnya, mereka tergantung pada satu sama lain. Chan et al (1999) dalam penelitiannya menunjukkan bukti keuntungan momentum yang secara statistik signifikan dan ekonomis, terutama untuk periode memegang jangka pendek (kurang dari 4 minggu). Goetzmann and Massa (2000) dalam penelitiannya menyimpulkan bahwa Secara khusus, penelitian ini telah menemukan pedagang umpan balik positif atau investor momentum.

Jegadeesh and Titman (2001) yang menyimpulkan dalam penelitiannya bahwa strategi investasi momentum masih terus menguntungkan sepanjang periode sampel setelah periode yang digunakan pada penelitian sebeiumnya (1965-1998). Cooper dan Gustierrez (2004) dalam penelitiannya menemukan bahwa laba strategi momentum tergantung pada keadaan pasar. George dan Hwang (2004) dalam penelitiannya menunjukkan bahwa ukuran 52 minggu memiliki daya prediksi apakah atau tidak pada saham individu memiliki return masa lalu yang ekstrim. Nugroho (2008) berhasil menemukan bahwa terdapat profitabilitas momentum pada pasar modal Indonesia selama periode Januari 2003 - Desember 2007.

- Serban (2009) dalam penilitiannya menyimpulkan bahwa menggunakan strategi trading, yang sebelumnya diterapkan hanya untuk pasar saham yang menciptakan abnormal return di pasar FX. Hasilnya juga kuat dibandingkan dengan strategi yang dikembangkan khusus untuk pasar FX. Biaya transaksi tidak mengubah hasii secara signifikan. Rastogi, et al (2009) meneliti momentum dan overreaction di pasar modal india menyimpulkan bahwa investor bisa memperoleh keuntungan dengan membeli winner dan menjual loser. Ali, et al (2009) yang menelitian apakah pasar Malaysia berreaksi berlebihan selama periode antara januari 1987 dan desember 2006. Penelitian ini mengungkapkan bahwa portofolio loser menunjukkan perilaku winner sedangkan portofolio winner menjadi loser dalam periode pengujian. Lobe dan Rieks (2010) penelitian yang berjudul pasar jangka pendek overreaction di pasar modal Frankfurt menyatakan bahwa 
saham di Jerman yang mengalami suatu peristiwa mendapatkan abnormal return jangka pendek. Penelitian ini menemukan bukti yang signifikan.

Ali, et al (2011) penelitian mengenai overreaction pasar saham dan volume perdagangan di Malaysia menemukan bukti kuat untuk mendukung hipotesis overreaction di pasar Malaysia untuk periode mulai dari 1 sampai 52 minggu. Berdasarkan temuan penelitian ini, strategi kontrarian membeli saham loser dan menjual saham winner bisa menghasilkan keuntungan yang signifikan terutama untuk jangka waktu antara 1 dan 12 minggu.

Berdasarkan hasil penelitian terdahulu, maka hipotesis dalam penelitian ini dirumuskan hipotesis sebagai berikut :

$$
\begin{array}{r}
\mathrm{H}_{0} \quad \mathrm{CAAR}_{\mathrm{w}_{, \mathrm{i}}}-\mathrm{CAAR}_{\mathrm{L}, \mathrm{t}}=0 \text { jika } \\
\text { hasil yang diperoleh sesuai } \\
\text { dengan kriteria menunjukan } \\
\text { momentum tidak terjadi }
\end{array}
$$

$\mathrm{H}_{1}$ CAAR $_{w_{t,}}-\mathrm{CAAR}_{\mathrm{L}, \mathrm{t}}>0$ jika hasil yang diperoieh sesuai dengan kriteria tersebut menunjukan hipotesis yang menyatakan momentum terjadi di terima

\section{METODE PENELITIAN}

Metode pengumpulan data yang digunakan dalam penilitian ini adalah dengan metode dokumentasi, dimana data yang digunakan merupakan data sekunder yang diperoleh dari Bursa Efek Indonesia, yang meliputi data harga saham individual bulanan dan harga saham yang diwakili oleh Indeks Harga Saham Gabungan (IHSG). Kedua jenis data ini dikumpulkan mulai dari tahun 2002 hingga 2012 .

\section{Metode yang di gunakan}

Dalam melakukan penelitian untuk membuktikan adanya momentum di BEI, penulis menggunakan metode dan cara perhitungan dengan mengunakan lamanya periode formasi dan observasi yang masingmasing selama satu tahun, dua tahun, tiga tahun, dan lima tahun lamanya periode penelitian, disini penulis hanya 3 bulan baik itu periode formasi dan observasi portofolio. Adapun langkah-langkah pengambilan sampel dijelaskan sebagai berikut :

1 Mencari informasi terlebih dahulu selama periode tahun 2002 sampai dengan tahun 2012, jika ditemukan sejumlah perusahaan yang baru listing perusahaan tersebut tidak dimasukan sebagai sampel.

2 Melakukan penghitungan return dari masing-masing saham, apabila terdapat saham yang tidak diperdagangkan pada salah satu tanggal dari periode penelitian maka harga saham tersebut disesuaikan dengan harga penutupan tanggal transaksi terakhir dari saham yang bersangkutan.

3 Selanjutnya melakukan perhitungan abnormal return dari masing-masing saham dengan menggunakan data IHSG yang terdapat dalam periode observasi, dalam hal ini data observasi yang diperoleh mengurutkannya secara ascending, maka akan memilih hasil abnormal return dari seluruh saham yang ada dengan kriteria sebagai berikut :

a. Untuk sampel saham-saham winner (atau disebut juga sebagai portofolio winner), maka peneliti memilih saham-saham yang termasuk dalam $30 \%$ data terbawah dari abnormal return berdasarkan periode formasi dan pengujian yang ada.

b. Untuk sampel saham-saham loser (atau disebut juga sebagai portofolio loser), maka peneliti memilih saham-saham yang termasuk dalam $30 \%$ data teratas dari abnormal return berdasarkan periode formasi dan pengujian yang ada.

Secara umum proses atau tahapan pembentukan portofolio yang digunakan dalam penelitian ini terlihat dibawah ini:

1. Menghitung return bulanan dari harga saham yang ada selama periode pembentukan yaitu selama 3 bulan, dipilihnya periode waktu perhitungan return selama tiga bulan karena pergerakan dari saham sifatnya adalah jangka pendek, sehingga didalam tiga bulan diprediksi nilai harga pasar saham secara psikologis tentu di prediksi akan berubah, sehingga dapat dijadikan alat untuk membantu gejala terjadinya momentum. Secara umum return saham dapat dicari dengan rumus (Jogiyanto, 2003) : 
Dimana:

$$
R_{i t}=\frac{P_{i t}-P_{i t-1}}{P_{i t-1}}
$$

$\mathrm{R}_{\mathrm{it}}$ : Return sesungguhnya

$\mathrm{P}_{\mathrm{it}}$ : Harga penutupan (closing price) saham i pada waktu $\mathrm{t}$

$\mathrm{P}_{\mathrm{it}-1}$ : Harga penutupan (closing proce) saham i pada waktu t-1

2. Menghitung return pasar bulanan, dengan rumus (Jogiyanto, 2003) :

Dimana:

$$
R_{m t}=\frac{I H S G_{t}-I_{H S G} t-1}{I H S G_{t-1}}
$$

$$
\begin{array}{llll}
\mathrm{R}_{\mathrm{mt}} & : & \text { Return pasar } & \\
\mathrm{IHSG}_{\mathrm{t}}: & \text { IHSG (closing price) } & \text { saham } \\
& & \text { pada waktu } \mathrm{t} \\
\mathrm{IHSG}_{\mathrm{t}-1}: & \text { IHSG (closing price) } & \text { saham } \\
& & \text { waktu t-1 }
\end{array}
$$

3. Menghtung Abnormal return dihitung dengan cara mengurangi return saham dengan return pasar seperti terlihat pada rumus berikut ini (Jogiyanto, 2003):

$$
A R_{\mathrm{t}}=\mathrm{R}_{\mathrm{it}}-\mathrm{R}_{\mathrm{mt}}
$$

Dimana:

$\mathrm{AR}_{\mathrm{t}}$ : Return tidak normal (abnormal return) saham pada bulan ke $t$

$\mathrm{R}_{\mathrm{it}}$ : Return saham $\mathrm{i}$ pada bulan $\mathrm{t}$

$\mathrm{R}_{\mathrm{mt}}$ : Return pasar pada bulan $\mathrm{t}$

4. Mengkumulatifkan return selama tiga bulan (formation period) untuk membentuk CAR tiga bulan:

$$
\mathrm{CAR}_{\mathrm{i}, \mathrm{t}}=\sum_{\mathrm{i}-1}^{\mathrm{n}} \mathrm{AR}_{\mathrm{i}, \mathrm{t}}
$$

Dimana:

$\mathrm{CAR}_{i, t}$ : Cumulative Abnormal Return saham i pada waktu $t$ (triwulan ke-t, dimana $\mathrm{t}=1,2,3$..)

$\mathrm{AR}_{\text {is }}$ : Abnormal Return i pada waktu $\mathrm{t}$ (triwulan ke-t, dimana $\mathrm{t}=1,2$, 3..)

Setelah terbentuk portofolio winner dan loser, maka tahap berikutnya adalah mengamati perilaku return pada periode observasi atau penggujian. Secara lebih jelas, tahap-tahap pada periode observasi dengan metode ini adalah sebagai berikut :

I Menghitung return bulanan, untuk sahamsaham yang termasuk dalam kedua portofolio, dengan menggunakan harga saham yang ada selama periode observasi.

2 Menghitung return pasar bulanan dengan menggunakan Indeks Harga Saham Gabungan. Perhitungan return pasar dilakukan sesuai dengan periode observasi selama triwulan.

3 Menghitung abnormal return saham triwulan untuk saham-saham pada portofolio winner dan loser, dengan rumus (Jogiyanto, 2003):

Dimana:

$$
A R_{t}=R_{i t}-R_{m t}
$$

$\mathrm{AR}_{\mathrm{t}}$ : Return tidak normal (abnormal return) saham pada bulan ke $\mathrm{t}$

$\mathrm{R}_{\mathrm{it}}$ : Return saham i pada bulan $\mathrm{t}$

$\mathrm{R}_{\mathrm{mt}} \quad$ : Return pasar pada bulan t

4 Menghitung CAR portofolio winner dan loser selama jangka waktu periode observasi, dengan rumus :

Dimana :

$$
\mathrm{CAR}_{\mathrm{p}, \mathrm{T}}=\Sigma \mathrm{AR}_{\mathrm{p}, \mathrm{t}}
$$

$\mathrm{CAR}_{\mathrm{pT}}=$ cumulative abnormal return portofolio (baik winner maupun loser) selama T hari.

$\mathrm{AR}_{\mathrm{p}, \mathrm{t}}=$ abnormal return portofolio pada hari ke-t.

5 Setelah CAR portofolio winner dan loser diperoleh, maka tahap selanjutnya adalah mencari abnormal profit yang ada. Abnormal profit ini diperoleh dengan cara mengurangi CAR portofolio winner dengan CAR portofolio loser selama periode observasi.

6 Menghitung CAAR (Cumulative Average Abnormal Return) portofolio winner. CAAR dengan rumus :

$$
\begin{aligned}
\text { CAAR }_{\mathrm{w}, \mathrm{t}} & =\frac{\sum_{\mathrm{i}=1}^{\mathrm{k}} \mathrm{CAR}_{\mathrm{W}, \mathrm{i}, \mathrm{t}}}{\mathrm{K}} \\
\mathrm{CAAR}_{\mathrm{L}, \mathrm{t}} & =\frac{\sum_{\mathrm{i}=1}^{\mathrm{k}} \mathrm{CAR}_{\mathrm{L}, \mathrm{i}, \mathrm{t}}}{\mathrm{K}}
\end{aligned}
$$

Dimana: 
$\mathrm{CAAR}_{\mathrm{W}, t}$ : Akumulasi rata-rata return tidak normal (cummulative average abnormal return) winner pada hari ke-t

$\mathrm{CAAR}_{\mathrm{L}, \mathrm{t}}$ : Akumulasi rata-rata return tidak normal (cummulative average abnormal return) loser pada hari ke-t

$\mathrm{CAR}_{\mathrm{w}, l, \mathrm{t}}$ : Akumulasi return tidak normal (cummulative abnormal return) winner sekuritas ke-i pada hari ke-t

$\mathrm{CAR}_{\mathrm{L}, \mathrm{l}, \mathrm{t}}$ : Akumulasi return tidak normal (cummulative abnormal return) loser sekuritas ke-i pada hari ke-t

k : Jumlah sekuritas yang terpengaruh oleh pengumuman peristiwa

7 Menghitung selisih CAAR portofolio loser dengan CAAR portofolio winner dengan rumus :

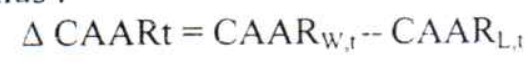

Dimana:

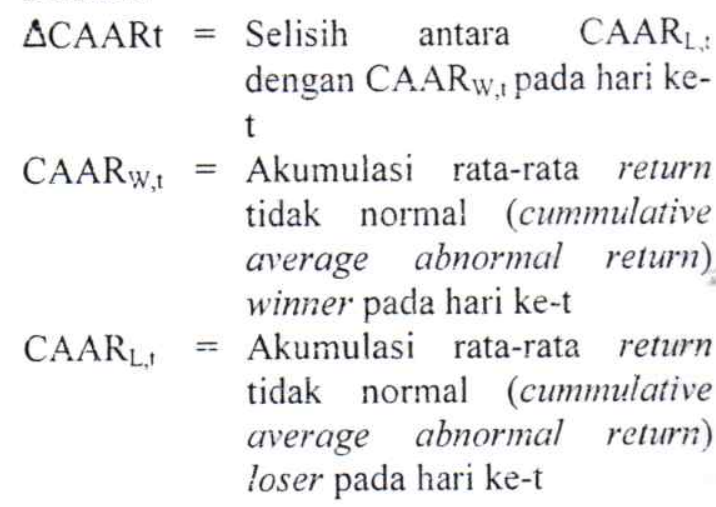

8 Menghitung t-statistic untuk menguji tingkat signifikansi selisih nilai CAAR loser dan CAAR winner. Pada model pengujian nilai tingkat kesalahan yang digunakan adalah 0,05 . Jika nilai signifikan yang diperoleh berada dibawah tingkat kesalahan menunjukan adanya perbedaan yang signifikan dan sebaliknya.

9 Menarik kesimpulan ada tidaknya anomali winner loser berdasarkan hasil yang diperoleh.

\section{PEMBAHASAN}

\section{Mengidentifikasi Nilai Abnormal Profit}

Pada Tabel 1 terlihat terjadi variasi nilai Abnormal Profit sepanjang periode observasi. Jika lihat dari bulan pertama periode observasi nilai rata rata Abnormal Profit yang diperoleh adalah sebesar 2,45267 nilai tersebut menunjukan bahwa nilai Abnormal Profit yang diperoleh oleh investor akan menunjukan perkembangan naik, sedangkan nilai standar deviasi yang diperoleh dalam pengujian adalah sebesar 2,42878. Jika dilakukan pengujian secara statistik diperoleh nilai t-hitung sebesar 6,622 dengan nilai signifikan sebesar 0,000. Tahapan pengolahan data dilakukan dengan menggunakan tingkat kesalahan sebesar 0,05 . Hasil yang diperoleh menunjukan bahwa nilai signifikan sebesar $0,000<$ alpha 0,05 maka dapat disimpulkan terjadi perbedaan nilai Abnormal Profit pada bulan pertama periode observasi dengan kecenderungan naik.

Pada bulan kedua diperoleh nilai rata rata Abnormal Profit sebesar 0,96876 nilai tersebut menunjukan bahwa terjadi kecenderungan naik dari nilai rata rata Abnormai Profit yang diperoleh oleh investor, hasil pengujian juga menunjukan nilai standar deviasi sebesar 1,50203. Pada tahapan observasi diperoleh nilai t-hitung sebesar 4,229 dengan tingkat singnifikan sebesar 0,000 . Tahapan pengolahan data dilakukan dengan menggunakan tingkat kesalahan sebesar 0,05 . Hasil yang diperoleh menunjukan bahwa nilai signifikan sebesar $0,000<$ alpha 0,05 maka dapat disimpulkan bahwa terdapat perbedaan nilai Abnormal Profit dalam hal ini kecenderungan yang terjadi adalah penurunan nilai Abnormal Profit dari periode bulan pertama kebulan kedua.

\section{Analisis Cumulative average abnormal return Antara Perusahaan Loser dan Winner}

Pada Tabel 2 terlihat nilai rata rata hasil pengurangan antara cumulative average abnormal return perusahaan winner dengan loser adalah sebesar 2,54273, didalam hal pengujian diperoleh nilai standar deviasi sebesar 1,54679. Hasil yang diperoleh menunjukan kecenderungan dari portofolio winner menunjukan kenaikan cumulative average abnormal return, didalam tahapan 
pengujian statistik diperoleh nilai t-hitung sebesar 10,780. Tahapan pengolahan data dilakukan dengan menggunakan tingkat kesalahan 0,05. Hasil yang diperoleh mengidentifikasikan bahwa nilai signifikan $0,000<$ alpha 0,05 maka dapat disimpulkan terdapat perbedaan nilai cumulative average abnormal return setelah dilakukan pengurangan winner dengan loser. Hasil tersebut menunjukan bahwa kecenderungan perusahaan winner untuk terus mengugguli perusahaan loser akan terus terjadi, sehingga strategi momentum terjadi.

Dalam penelitian ini menunjukkan momentum strategi investasi dapat dilakukan dengan baik oleh perusahaan winner. Dalam hal ini manajemen perusahaan winner berusaha menjaga momentum posisi mereka dipasar sekunder, dalam hal ini perusahaan winner terus mempertahan komposisi nilai pasar yang tinggi, dengan cara menjaga stabilitas kinerja keuangan dan menjaga image perusahaan didalam pandangan investor atau pelaku pasar. Kondisi ini juga menunjukan bahwa loser terus berada dalam posisi yang sama, walaupun mereka berusaha menciptakan momentum untuk memperbaiki posisi dari perusahaan loser ke perusahaan winner.

\section{Kesimpulan}

Berdasarkan kepada analisis dan pembahasan hasil pengujian hipotesis dapat diajukan sejumlah kesimpulan yang merupakan jawaban dari permasalahan yang dibahas didalam penelitian ini yaitu:

1. Berdasarkan analisis data teridentifikasi bahwa terdapat perbedaan nilai Abnormal Profit pada perusahaan loser maupun winner, didalam penelitian teridentifikasi nilai rata rata Abnormal Profit yang diperoleh adalah positif, dalam hal ini Abnormal Profit perusahaan winner masih menunjukan kecenderungan naik, sedangkan perusahaan loser terus menunjukan Abnormal Profit dengan kondisi sebaliknya.

2. Hasil analisis yang dihasilkan juga menunjukan bahwa nilai cumulative average abnormal return perusahaan winner jauh lebih unggul dari average abnormal return perusahaan loser. Kondisi ini menunjukan aktifitas investasi yang dilakukan pelaku pasar lebih baik dilakukan pada perusahaan winner.

3. Hasil analisis data menunjukan bahwa terdapat perbedaan yang signifikan nilai cumulative average abnormal return setelah dilakukan pengurangan antara perusahaan winner dengan loser. Kecenderungan yang terjadi adalah kenaikan. Kondisi ini menunjukan bahwa momentum perusahaan winner untuk terus menjaga posisinya selalu terjaga dengan baik.

\section{DAFTAR PUSTAKA}

Ahmad, Kamaruddin. 2004. "Dasar-dasar Manajemen Investasi dan Portofolio". Edisi Revisi. Jakarta : PT. Asdi Mahasatya.

Ali Ruhani, Ahmad Zamri and Anusakumar S. 2011. "Stock Market Overreaction and TrandingVolume Evidence From Malaysia". AAMJAF Vol. 7 No. 2. 103119

Ali Norli, Nasssir, HassanTaufiq and AbidinSazali Z. 2009. "Does Bursa Malaysia Overreact". International Research Journal Of Finance and Economic. ISSN 1450-2887 Issue 34

Anusakumar, Ali dan Wooi. 2012. "Momentum and Investor Sentiment : Evidence from Asian Stock Markets".

Asness, Clifford. 1997. "The Interaction of Value and Momentum Strategi". Financial Analyst Journal.

Chan Kolok, Hameed Allaudeen and Tong Wilsom. 1999. "Profitability of Momentum Strategies in the International Equity Markets". Departement of Finance Hong Kong University of Science and Technology.

Cooper, M and Gutierrez R. 2004. "Market Stated and Momentum". The Journal of Finance. Vol. LIX. No. 3.

De Bond, W and R Thaler. 1985. "Does security Analysts Overreact?".The American Economic Review. Volume 80. 52-57.

Fama, F Eguene.1997. "Market Efficiency, Long-Term Return and Behavioral Finance".Journal of Financial Economic; Vol. 49. 283-306. 
George Thomas and Hwang Chuan-yang. 2004. "The 52-Week High and Momentum Investing". The Journal of Finance. Vol. LIX. No. 5

Goetzmann W and Massa M. 2000. "Daily Momentum and Contarian Behavior of Index Fund Investors". National Bureau of Economic Research.

Husnan, S. 2005. "Dasar-dasar Teori Portofolio dan Analisis Sekuritas". Yogyakarta : UPP AMP YKPN

Jegadeesh, $\mathrm{N}$ and S. Titman. 2001. "Profitability of Momentum Strategies: An Evaluation of Alternative Explanations", The Journal of Finance, Vol. LVI (2), pp.699-720.

Jogiyanto.2003. "Teori Portofolio dan Analisis Investasi". Edisi Ketiga. Yogyakarta : BPFE.

Kowanda, Dionsyia dan Pasaribu, Bismark. 2012. "Strategi Investasi Momentum: Profit Momentum Portofolic PemenangPecundang di Indonesia". Journal of Economics and Business. ISSN : 19783116. Vol. 5. No.5. Hal. 87-115.

Lobe Sebastian and Rieks Juhannes. 2010. "Short-Term Market Overreaction on the Frankfurt Stock Exchange". Center Of Finance, University Of Regensburg : Germany.

Nugroho , Yuliarto. 2008. "Profitabilitas Strategi Momentum di Bursa Efek Indonesia (Periode Januari 2003 -
Desember2007)". Jurnal Siasat Bisnis Vol. 12 No. 3, Hal: 175-186

Rastogi Nikhil, Chaturvedula Chakrapani dan Bang Nupur Pavan. 2009. "Momentum and Overreaction in Indian Capital Market". International Research Journal of Fiance and Economics. ISSN 14502887 issue 32

Santoso, Agus. 2000. "Overreaction of the Indonesia Capital Market". Gajah Mada International Jurnal of Buainess, Vol.2

Samsul, Mohamad. 2006. "Pasar Modal dan Manajemen Portofolio". Jakarta : Erlangga.

Serban, Alina. 2009. "Combining Mean Reversion and Momentum Trading Strategies in Foreign Exchange Markets". Departement of Economics, West Virginia University.

Sharpe. 1995. "The Investmen Theory of Party Compotition". Printed in The United Stated of Amerika.

Pasaribu, Fernando. 2011. "Anomali Overreaction di Bursa Efek Indonesia".ISSN : 1978-3116. Vol. 5, No. 2.

Tandelilin, Eduardus. 2001. "Analisis Investasi dan Manajemen Portofolio". Edisi Pertama. Yogyakarta : BPFE.

Zarowi, Paul. 1990 "Size, Seasonality, and Stock Market Overreaction'. Journal Financial and Quantitative Analysis, Vol. 25, No. 1: 113-125.

\section{Tabel 1}

Perkembangan Nilai Abnormal Profit

\begin{tabular}{|c|r|r|r|}
\hline \multirow{2}{*}{ Observasi } & \multicolumn{3}{|c|}{ Winner-loser } \\
\cline { 2 - 4 } & \multicolumn{1}{|c|}{ Bulan 1 } & Bulan 2 & \multicolumn{1}{c|}{ Bulan 3 } \\
\hline 1 & 14.64861 & 0.10687 & 2.20714 \\
\hline 2 & 3.15822 & 0.12035 & 3.26815 \\
\hline 3 & 1.6837 .4 & 1.24486 & 5.17747 \\
\hline 4 & 3.85411 & -1.74408 & 3.60621 \\
\hline 5 & 3.12340 & -0.98874 & -0.34060 \\
\hline 6 & 1.61569 & -0.67023 & -1.03922 \\
\hline 7 & 1.20315 & -1.55665 & -0.73544 \\
\hline 8 & 1.15060 & 2.15789 & 2.09156 \\
\hline 9 & 2.62009 & 0.07099 & 3.34593 \\
\hline 10 & 1.66081 & -0.76142 & 0.75508 \\
\hline 11 & 4.90564 & -0.53640 & 0.82588 \\
\hline 12 & 3.10439 & -0.63967 & 3.09717 \\
\hline 13 & -1.05730 & 0.17562 & 3.19737 \\
\hline 14 & 0.69252 & 1.44128 & 1.21354 \\
\hline 15 & 2.66878 & 1.19884 & 2.90588 \\
\hline 16 & 1.49712 & 0.47664 & 3.64054 \\
\hline 17 & 0.19401 & 1.38535 & 2.44372 \\
\hline 18 & 2.60491 & -0.01635 & 2.27317 \\
\hline
\end{tabular}




\begin{tabular}{|c|c|c|c|}
\hline 19 & 3.09187 & 0.41592 & 0.13050 \\
\hline 20 & 3.30648 & 2.98422 & 0.58465 \\
\hline 21 & 3.01092 & 3.41248 & -2.35078 \\
\hline 22 & 1.38687 & 1.26959 & -0.70590 \\
\hline 23 & 4.20359 & 1.09121 & 3.45746 \\
\hline 24 & 3.60212 & 2.01354 & 1.77669 \\
\hline 25 & -0.41220 & 3.57729 & 3.02633 \\
\hline 26 & 1.18205 & 3.49846 & 4.19441 \\
\hline 27 & 4.09032 & 1.89648 & 0.93417 \\
\hline 28 & 4.31949 & 1.78057 & -1.56889 \\
\hline 29 & 0.43429 & 3.87570 & 0.63396 \\
\hline 30 & -1.02772 & 3.51763 & 2.01060 \\
\hline 31 & 0.64898 & 1.95293 & 1.51485 \\
\hline 32 & 1.90358 & 2.39617 & 1.75925 \\
\hline 33 & 2.29295 & 2.17986 & 1.89127 \\
\hline 34 & 2.48153 & 1.59428 & 1.99729 \\
\hline 35 & 3.30842 & 0.52705 & 1.90202 \\
\hline 36 & 0.92719 & -0.95615 & 0.87210 \\
\hline 37 & -0.52135 & -1.69888 & 0.53124 \\
\hline 38 & 2.33850 & 0.18110 & 0.43294 \\
\hline 39 & 4.12356 & 0.76698 & 0.26499 \\
\hline 40 & 4.26976 & -0.24486 & 2.68527 \\
\hline 41 & 3.51980 & 1.30287 & 3.49120 \\
\hline 42 & 2.21325 & 2.07974 & 2.51294 \\
\hline 43 & 1.44217 & 0.77757 & 1.64057 \\
\hline Rata Rata & 2.45267 & 0.96876 & 1.66401 \\
\hline Std Deviası & 2.42878 & 1.50203 & 1.62778 \\
\hline T-hit & 6.622 & 4.229 & 6.703 \\
\hline Sig & 0,000 & 0,000 & 0,000 \\
\hline
\end{tabular}

Tabel 2

Perkembangan Nilai Cumulative Average Abnormal Return (Winner - Loser)

\begin{tabular}{|c|c|c|c|c|}
\hline \multirow{2}{*}{ Observasi } & \multicolumn{3}{|c|}{ CAAR Kombinasi } & \multirow[b]{2}{*}{ W-L } \\
\hline & Bulan 1 & Buian 2 & Bulan 3 & \\
\hline 1 & 7.32431 & 0.05343 & 1.10357 & 8.48131 \\
\hline 2 & 1.57911 & 0.06018 & 1.63408 & 3.27336 \\
\hline 3 & 0.84187 & 0.62243 & 2.58874 & 4.05304 \\
\hline 4 & 1.92706 & -0.87204 & 1.80310 & 2.85812 \\
\hline 5 & 1.56170 & $\because-0,49437$ & -0.17030 & 0.89703 \\
\hline 6 & 0.80784 & $-0.335 ! 1$ & $-0.5 i 961$ & -0.04688 \\
\hline 7 & 0.60157 & -0.77832 & -0.36772 & -0.54447 \\
\hline 8 & 0.57530 & 1.07895 & 1.04578 & 2.70003 \\
\hline 9 & 1.31005 & 0.03549 & 1.67296 & 3.01850 \\
\hline 10 & 0.83040 & -0.38071 & 0.37754 & 0.82724 \\
\hline 11 & 2.45282 & -0.26820 & 0.41294 & 2.59756 \\
\hline 12 & 1.55219 & -0.31984 & 1.54858 & 2.78094 \\
\hline 13 & -0.52865 & 0.08781 & 1.59869 & 1.15785 \\
\hline 14 & 0.34626 & 0.72064 & 0.60677 & 1.67367 \\
\hline 15 & 1.33439 & 0.59942 & 1.45294 & 3.38675 \\
\hline 16 & 0.74856 & 0.23832 & 1.82027 & 2.80715 \\
\hline 17 & 0.09701 & 0.69268 & 1.22186 & 2.01154 \\
\hline 18 & 1.30245 & -0.00817 & 1.13658 & 2.43087 \\
\hline 19 & 1.54594 & 0.20796 & 0.06525 & 1.81915 \\
\hline 20 & 1.65324 & 1.49211 & 0.29233 & 3.43767 \\
\hline 21 & 1.50546 & 1.70624 & -1.17539 & 2.03631 \\
\hline 22 & 0.69343 & 0.63479 & -0.35295 & 0.97528 \\
\hline 23 & 2.10180 & 0.54561 & 1.72873 & 4.37613 \\
\hline 24 & 1.80106 & 1.00677 & 0.88835 & 3.69618 \\
\hline 25 & -0.20610 & 1.78865 & 1.51317 & 3.09572 \\
\hline 26 & 0.59102 & 1.74923 & 2.09721 & 4.43746 \\
\hline 27 & 2.04516 & 0.94824 & 0.46709 & 3.46049 \\
\hline 28 & 2.15974 & 0.89028 & -0.78444 & 2.26558 \\
\hline 29 & 0.21714 & 1.93785 & 0.31698 & 2.47197 \\
\hline 30 & -0.51386 & 1.75881 & 1.00530 & 2.25025 \\
\hline 31 & 0.32449 & 0.97646 & 0.75743 & 2.05838 \\
\hline 32 & 0.95179 & 1.19809 & 0.87962 & 3.02950 \\
\hline
\end{tabular}




\begin{tabular}{|c|c|c|c|}
\hline 19 & 3.09187 & 0.41592 & 0.13050 \\
\hline 20 & 3.30648 & 2.98422 & 0.58465 \\
\hline 21 & 3.01092 & 3.41248 & -2.35078 \\
\hline 22 & 1.38687 & 1.26959 & -0.70590 \\
\hline 23 & 4.20359 & 1.09121 & 3.45746 \\
\hline 24 & 3.60212 & 2.01354 & 1.77669 \\
\hline 25 & -0.41220 & 3.57729 & 3.02633 \\
\hline 26 & 1.18205 & 3.49846 & 4.19441 \\
\hline 27 & 4.09032 & 1.89648 & 0.93417 \\
\hline 28 & 4.31949 & 1.78057 & -1.56889 \\
\hline 29 & 0.43429 & 3.87570 & 0.63396 \\
\hline 30 & -1.02772 & 3.51763 & 2.01060 \\
\hline 31 & 0.64898 & 1.95293 & 1.51485 \\
\hline 32 & 1.90358 & 2.39617 & 1.75925 \\
\hline 33 & 2.29295 & 2.17986 & 1.89127 \\
\hline 34 & 2.48153 & 1.59428 & 1.99729 \\
\hline 35 & 3.30842 & 0.52705 & 1.90202 \\
\hline 36 & 0.92719 & -0.95615 & 0.87210 \\
\hline 37 & -0.52135 & -1.69888 & 0.53124 \\
\hline 38 & 2.33850 & 0.18110 & 0.43294 \\
\hline 39 & 4.12356 & 0.76698 & 0.26499 \\
\hline 40 & 4.26976 & -0.24486 & 2.68527 \\
\hline 41 & 3.51980 & 1.30287 & 3.49120 \\
\hline 42 & 2.21325 & 2.07974 & 2.51294 \\
\hline 43 & 1.44217 & 0.77757 & 1.64057 \\
\hline Rata Rata & 2.45267 & 0.96876 & 1.66401 \\
\hline Std Deviası & 2.42878 & 1.50203 & 1.62778 \\
\hline T-hit & 6.622 & 4.229 & 6.703 \\
\hline Sig & 0,000 & 0,000 & 0,000 \\
\hline
\end{tabular}

Tabel 2

Perkembangan Nilai Cumulative Average Abnormal Return (Winner - Loser)

\begin{tabular}{|c|c|c|c|c|}
\hline \multirow{2}{*}{ Observasi } & \multicolumn{3}{|c|}{ CAAR Kombinasi } & \multirow[b]{2}{*}{ W-L } \\
\hline & Bulan 1 & Buian 2 & Bulan 3 & \\
\hline 1 & 7.32431 & 0.05343 & 1.10357 & 8.48131 \\
\hline 2 & 1.57911 & 0.06018 & 1.63408 & 3.27336 \\
\hline 3 & 0.84187 & 0.62243 & 2.58874 & 4.05304 \\
\hline 4 & 1.92706 & -0.87204 & 1.80310 & 2.85812 \\
\hline 5 & 1.56170 & $\because-0,49437$ & -0.17030 & 0.89703 \\
\hline 6 & 0.80784 & $-0.335 ! 1$ & $-0.5 i 961$ & -0.04688 \\
\hline 7 & 0.60157 & -0.77832 & -0.36772 & -0.54447 \\
\hline 8 & 0.57530 & 1.07895 & 1.04578 & 2.70003 \\
\hline 9 & 1.31005 & 0.03549 & 1.67296 & 3.01850 \\
\hline 10 & 0.83040 & -0.38071 & 0.37754 & 0.82724 \\
\hline 11 & 2.45282 & -0.26820 & 0.41294 & 2.59756 \\
\hline 12 & 1.55219 & -0.31984 & 1.54858 & 2.78094 \\
\hline 13 & -0.52865 & 0.08781 & 1.59869 & 1.15785 \\
\hline 14 & 0.34626 & 0.72064 & 0.60677 & 1.67367 \\
\hline 15 & 1.33439 & 0.59942 & 1.45294 & 3.38675 \\
\hline 16 & 0.74856 & 0.23832 & 1.82027 & 2.80715 \\
\hline 17 & 0.09701 & 0.69268 & 1.22186 & 2.01154 \\
\hline 18 & 1.30245 & -0.00817 & 1.13658 & 2.43087 \\
\hline 19 & 1.54594 & 0.20796 & 0.06525 & 1.81915 \\
\hline 20 & 1.65324 & 1.49211 & 0.29233 & 3.43767 \\
\hline 21 & 1.50546 & 1.70624 & -1.17539 & 2.03631 \\
\hline 22 & 0.69343 & 0.63479 & -0.35295 & 0.97528 \\
\hline 23 & 2.10180 & 0.54561 & 1.72873 & 4.37613 \\
\hline 24 & 1.80106 & 1.00677 & 0.88835 & 3.69618 \\
\hline 25 & -0.20610 & 1.78865 & 1.51317 & 3.09572 \\
\hline 26 & 0.59102 & 1.74923 & 2.09721 & 4.43746 \\
\hline 27 & 2.04516 & 0.94824 & 0.46709 & 3.46049 \\
\hline 28 & 2.15974 & 0.89028 & -0.78444 & 2.26558 \\
\hline 29 & 0.21714 & 1.93785 & 0.31698 & 2.47197 \\
\hline 30 & -0.51386 & 1.75881 & 1.00530 & 2.25025 \\
\hline 31 & 0.32449 & 0.97646 & 0.75743 & 2.05838 \\
\hline 32 & 0.95179 & 1.19809 & 0.87962 & 3.02950 \\
\hline
\end{tabular}


116 Jurnal Matua, Vol. 2, No. 2, Agustus 2015, $107-116$

\begin{tabular}{|c|c|c|c|c|}
\hline 33 & 1.14648 & 1.08993 & 0.94564 & 3.18204 \\
\hline 34 & 1.24077 & 0.79714 & 0.99865 & 3.03655 \\
\hline 35 & 1.65421 & 0.26353 & 0.95101 & 2.86874 \\
\hline 36 & 0.46359 & -0.47807 & 0.43605 & 0.42157 \\
\hline 37 & -0.26067 & -0.84944 & 0.26562 & -0.84449 \\
\hline 38 & 1.16925 & 0.09055 & 0.21647 & 1.47627 \\
\hline 39 & 2.06178 & 0.38349 & 0.13249 & 2.57776 \\
\hline 40 & 2.13488 & -0.12243 & 1.34263 & 3.35508 \\
\hline 41 & 1.75990 & 0.65143 & 1.74560 & 4.15693 \\
\hline 42 & 1.10662 & 1.03987 & 1.25647 & 3.40297 \\
\hline 43 & 0.72108 & 0.38878 & 0.82029 & 1.93015 \\
\hline \multicolumn{4}{|l|}{ Rata Rata } & 2.54273 \\
\hline \multicolumn{4}{|l|}{ Standar Deviasi } & 1.54679 \\
\hline \multirow{2}{*}{\multicolumn{4}{|c|}{$\frac{\text { t-hitung }}{\text { Sig }}$}} & 10,780 \\
\hline & & & & 0,000 \\
\hline
\end{tabular}

